\title{
OBRIGAÇÕES E A CONSTRUÇÃO DE VÍNCULOS NO CANDOMBLÉ
}

\author{
Miriam C. M. Rabelo ${ }^{1}$ \\ ${ }^{1}$ Universidade Federal da Bahia, Salvador, BA, Brasil
}

\section{Introdução}

Obrigação é uma palavra corrente no candomblé. Em quase todo terreiro há sempre alguém se preparando para dar uma obrigação ou já recolhido para tal. O termo é usado comumente em referência a rituais realizados após a feitura (iniciação), mas em um sentido mais amplo fala de um modo próprio de construir e cuidar de vínculos ao longo do tempo, que é característico do candomblé. Neste texto ${ }^{1}$ uso um conjunto variado de materiais - entrevistas, notas escritas, eventos registrados em campo e postagens no Facebook, além de minha experiência como adepta do candomblé - para explorar as muitas nuances desse modo de vincular humanos e entidades, e entender seus efeitos ético-políticos na dinâmica relacional dos terreiros e na vida de seus participantes.

O percurso que pretendo percorrer começa a certa distância do dia a dia das casas de candomblé - uma entrevista em que um pai de santo é instado a falar sobre obrigação para um público mais amplo e provocado a desfazer alguns dos mal-entendidos em torno do seu significado. É a partir do esforço do pai de santo em se fazer entender que me aproximo do terreiro, procurando iluminar a conexão entre o argumento que ele desenvolve - o modo como procura definir obrigação para o entrevistador - e a trajetória que as obrigações desenham para os filhos de santo. Se nesse momento me concentro em descrever elementos centrais dessa trajetória e iluminar o mundo que resulta do seu traçado, na seção seguinte parto de uma situação de conflito em um terreiro para explorar melhor o tipo de questão e problema que as obrigações colocam aos filhos de santo.

Na conclusão me afasto novamente do terreiro e de certo modo retomo alguns pontos suscitados pela entrevista. Mas minha intenção não é reforçar, com esse movimento, a distância entre o modo como os vínculos são construídos no candomblé e o modo como o candomblé se relaciona com quem está fora. É antes pensar possíveis conexões entre os dois. 


\section{Obrigação/Abrigação}

Em 5 de agosto de 2011 Jô Soares recebeu em seu programa Tata Mutá Imé, pai de santo baiano da nação Angolão Paquetã. A certa altura da entrevista, Jô perguntou a Tata:

- Me explica o seguinte, obrigações. Como é que fica o negócio das obrigações... Não sei se na sua nação tem, tem que ter...

- Sim, a gente não chama de obrigação. Na verdade, na nossa visão a gente não é obrigado a nada.

- Tudo bem, mas chama como?

- Abrigação.

- Abrigação.

- Abrigar em si a responsabilidade por estar vivo e pertencer àquela comunidade.

- Tem matança?

- Tem.

- Como é que fica do ponto de vista hoje em dia tão ecológico, tão ambientalista, e tal, como é que são encaradas essas abrigações quando, dependendo do pedido, às vezes tem até, mata-se até boi. Não é verdade?

- Hum hum.

- Não fica uma coisa conflitante com a ecologia, vamos chamar assim...

- Essa é uma boa pergunta porque nós, enquanto protetores da natureza, sabemos que o candomblé é uma religião que protege muito a natureza. Sem ela, sem a água, sem mato, a gente não sobrevive. Agora existe uma coisa da tradição. Nem sempre a gente precisa dar esses animais. Pra dar esses animais a gente pede licença, a gente canta, né, pra eles, a gente pergunta pra eles, em cânticos e palavras se ele quer ser morto, se ele quer...

- Pergunta se ele quer? E ele fala que quer?

- Vai-se ao jogo, vai-se ao jogo. A gente joga búzios pra isso, pra perguntar...

- Por isso que se diz que o bom cabrito não berra.

Ambos riem e a plateia acompanha.

- Ficou quietinho tudo bem...

- Ficou quietinho, aceitou fazer essa transferência de energia.

A entrevista seguiu por mais uns 10 minutos, durante os quais Tata Mutá pôde falar mais um pouco sobre sua história. O entrevistador manteve um tom jocoso e o entrevistado manteve o bom humor, procurando sutilmente reverter alguns dos estereótipos com os quais era confrontado com explicações mais detalhadas acerca das práticas que suscitavam a curiosidade do entrevistador. Algumas vezes a impressão de que estávamos assistindo ao desenrolar de uma interlocução amistosa entre dois sujeitos bem-humorados 
dava lugar à percepção de que se tratava antes de uma troca desigual entre o entrevistador branco do Sul e o pai de santo negro do Nordeste.

Nessa troca, Jô Soares concentrou sua atenção em práticas e termos que provavelmente tinham maior probabilidade de causar estranhamento em uma plateia pouco familiarizada com o candomblé - como matança e obrigação. À medida que questionava o pai de santo sobre essas práticas e termos, delineava-se o enquadre a partir do qual a plateia deveria entendê-los. Nele parecia estar implícita uma oposição entre dois tipos de moralidade. De um lado, a moralidade da obrigação, termo que sugere a ideia de uma vida regida por prescrições rígidas e a demandar menos convicção que obediência e que, além de tudo, no candomblé, inclui obrigação de matar animais. De outro lado, uma moralidade supostamente mais elevada em que as prescrições normativas são justificadas à luz de valores últimos e os indivíduos são capazes de escolher entre alternativas de conduta e justificar seus atos relacionando regras e valores. Embora o entrevistador não fizesse referência a esta moralidade, ela parecia funcionar como pano de fundo a partir do qual a vida moral do candomblé era transformada em objeto de atenção. Na pergunta de Jô talvez pairasse a suposição de que em uma moralidade definida por obrigações, características como reflexividade, liberdade e escolha seriam sacrificadas pelo formalismo, a rigidez e a imposição: estar obrigado é estar preso a regras cujo sentido não precisa ser conhecido ou debatido para gerar conformidade.

Esse sentido não passou despercebido a Tata Mutá Imê. Ao substituir obrigação por abrigação - independentemente de quão corrente é este último termo entre o povo de santo - Tata Mutá provavelmente pretendia livrar-se do sentido de obrigação delineado acima e, portanto, da visão preconceituosa do candomblé como uma religião que sacrifica a liberdade e a responsabilidade em nome da obediência cega. Por isso insistiu "na nossa visão a gente não é obrigado a nada".

Obrigar/ser obrigado e abrigar/estar abrigado delimitam campos de prática ética aparentemente bem diferentes. Estariam esses campos relacionados no candomblé?

\section{Moralidade}

O candomblé é uma religião de matriz africana de caráter iniciático em que são cultuadas divindades conhecidas como orixás, voduns ou inquices. ${ }^{2}$ Estas se fazem presentes de diversas formas na vida de um terreiro. Baixam nos corpos de alguns adeptos (referidos como rodantes ${ }^{3}$ ) e durante 
as festas celebradas em sua homenagem dançam ao som dos atabaques e cantigas que evocam seus feitos e qualidades. Expressam sua vontade no jogo de búzios (procedimento divinatório). E descansam silenciosamente nos seus assentamentos - os objetos em que foram fixadas ou assentadas durante ritos específicos e para os quais são dirigidas as oferendas que, de tempos e tempos, elas requerem. Reponsáveis por cuidar dos orixás, os adeptos de um terreiro estão ligados por laços de parentesco de santo: ${ }^{4}$ são filhos de santo da liderança da casa (mãe ou pai de santo) que os iniciou no culto e irmãos de santo de todos aqueles que foram iniciados por ela. A hierarquia, baseada na senioridade, é um dos pilares da organização da família de santo e tanto nas festas públicas quanto no dia a dia das casas é bastente vísivel a distância que separa velhos e novos "no santo".

Os orixás são divindades cujos feitos, temperamentos e preferências são narrados em mitos e refletidos em complexos procedimentos rituais. Mas além de existirem em um plano geral, associados a um corpus mítico-ritual, ${ }^{5}$ as divindades no candomblé também existem em um plano individual, como orixá ou santo de uma pessoa. Cada filha de santo traz consigo "em sua cabeça" um conjunto de orixás na forma de uma sequência. Dentre estes, o primeiro da sequência é o seu orixá de frente ou o dono da cabeça. Este é o santo de quem ela é filha. A iniciação ou feitura "faz" a pessoa como filha de um santo e faz o santo ou orixá individual de quem ela é filha. A partir daí, ambos, a filha de santo e o seu orixá individual, ingressam em uma trajetória de crescimento e maturação que lhes permite ascender na hierarquia da casa.

Obrigação é justamente o termo que fala da trajetória de crescimento dos filhos de santo no candomblé. Define, por assim dizer, etapas dessa trajetória e permite identificar cada adepto segundo o cumprimento dessas etapas. Assim, filhos de santo devem dar obrigações, em geral de 1, 3, 7, 14 e 21 anos $^{6}$ após a sua feitura - submetendo-se a ritos que marcam a idade de iniciação e que têm uma estrutura semelhante a ela, envolvendo também período de reclusão, oferendas e uma festa pública. A cada obrigação que a filha de santo dá (ou "paga"), um ou mais dos seus orixás comem (recebem sacrifício animal). A obrigação fortalece, assim, seu vínculo com os orixás e permite-lhe subir na hierarquia do terreiro. Em linhas gerais, essas mudanças ganham expressão no corpo: nas vestimentas, nos adereços, movimentos e gestos e modos de tratamento a que têm direito tanto a filha quanto o seu santo. A obrigação de 7 anos é, dentre todas, a que produz uma transformação mais decisiva: com ela, a filha de santo deixa de ser iaô (noviça) para ingressar no grupo das "mais velhas" ou ebomis. 
Além desse sentido mais restrito, o termo obrigação é também empregado no dia a dia dos terreiros em referência a todo um campo de práticas em que as pessoas atendem às demandas daqueles aos quais estão vinculadas (tanto entidades mais-que-humanas quanto outros humanos que medeiam suas relações com essas entidades, notadamente a mãe ou o pai de santo da casa), incluindo-se aí oferendas, rezas, cuidado com os assentamentos dos santos, com as plantas e com objetos como adereços e roupas. O cotidiano é assim marcado por um desenrolar sem fim de obrigações, de tipo e peso variáveis, muitas das quais se imiscuem sem grande alarde no ritmo das conversas e dos afazeres de filhos da casa.

Interessada em entender o sentido de obrigação no candomblé, recorri à minha mãe de santo. Mãe Beata tem 45 anos de iniciação e em 1982 abriu sua casa de candomblé, o Ilê Logundé Alakey Koysan, localizado no bairro da Boca do Rio, em Salvador. Ela escreveu alguns pontos para guiar nossa conversa e depois me entregou suas notas:

1. Deus existe, nos protege, [disse] faz por ti que eu te ajudarei. Se temos como lubrificar, não vamos deixar enferrujar.

Manutenção: saber manter continuidade fortifica o axé para qualquer causa que venha a acontecer, nós estarmos preparados.

2. A importância da obrigação: renovação, se sentir segura. Um novo exercício para entrar em sintonia com o nosso orixá, reforçar as energias, fortificar o nosso axé, mostrar a humildade retornando ao nosso retiro espiritual em busca de concentração, de forças e sabedoria seguindo as instruções dos nossos mais velhos e por esse meio chegarmos até essa energia positiva. Retorna as nossas forças com fé e respeito e humildade, agradando com oferendas.

A importância das obrigações é somando, multiplicando o nosso axé e fé. Cultuar de maneira correta 1 ano, 3 anos, 7 anos, 14 anos, 21 anos - hierarquia, respeito à hierarquia.

3. Temos que lubrificar, não deixar enferrujar - é bom ter e saber manter "alerta" prática e teoria. Preparação antes, durante e depois.

Obrigação, me explica Mãe Beata, serve para dar manutenção à feitura. É um alerta para a necessidade de se fortalecer o axé (princípio ou força vital), de forma a garantir proteção contra as adversidades que sempre podem nos surpreender. Além de manutenção, Mãe Beata usa dois termos que falam da relação entre obrigação e feitura: a obrigação lubrifica, não deixar enferrujar o vínculo firmado na feitura. Os termos chamam a atenção para o desgaste natural desse vínculo e para o trabalho de mantê-lo. Seu emprego nos transporta diretamente para o cotidiano das oficinas, das técnicas, dos reparos. 
Assim, quando lhe pergunto sobre a importância de se manterem as obrigações em dia, Mãe Beata me conta o caso de um ogã, que morreu afogado na lagoa de Pituaçu. Muito seu amigo, o ogã costumava estar ao seu lado em todas as atividades do terreiro. Talvez por inveja da proximidade entre eles, a mãe biológica do ogã (também mãe de santo) fez um ebó para prejudicar Beata, mas no final o prejudicado foi seu filho: diferentemente de Beata, o ogã negligenciava suas obrigações e por isso foi presa fácil das forças lançadas contra ela.

Associada à necessidade de proteção e a um conjunto de práticas ou técnicas para manter o estado de proteção, a obrigação no candomblé parece distante da ideia de uma moralidade regida por obediência cega e com pouco espaço para o exercício da escolha (ideia que pairava como um não dito na entrevista de Tata Mutá a Jô Soares). Afinal, o pagamento da obrigação requer não apenas considerações em termos de benefício próprio (é meio de proteção e de ascensão na hierarquia do terreiro), mas também a aplicação de um conhecimento prático (do saber-fazer requerido para conduzir os muitos procedimentos envolvidos e, a depender das circunstâncias e da necessidade, realizar adaptações com base nesse conhecimento). Mas se essa constatação sugere que a imagem de indivíduos sob o comando de injunções morais rígidas é uma descrição muito pobre da vida que se desenrola nos terreiros, ela suscita naqueles que opõem a prática ética à ação interessada a objeção de que as obrigações no candomblé não poderiam constituir as bases de uma verdadeira ética/moralidade.

Não é difícil notar que reproduzi aqui alguns dos contrastes que vez ou outra reaparecem nas discussões sobre ética e/ou moralidade ${ }^{7}$ nas ciências sociais: ação desinteressada x ação interessada; liberdade x conformidade; reflexão x disposições inconscientes ou semiconscientes para agir. Em algumas abordagens esses contrastes são empregados como dicotomias para recortar e delimitar com clareza o campo daquilo que constitui a ação moral, em outras, são mobilizados para caracterizar tipos de moralidade que operam em situações ou configurações culturais e históricas diferentes. Durkheim e Parsons são bons exemplos da primeira posição: enquanto para Durkheim (2003) a ação moral é desinteressada, a ideia de que valores e normas devidamente interiorizados não podem se converter em objeto de reflexão é central na abordagem parsoniana à moralidade (Parsons 2010). Robbins (2007) e Zigon (2007) são exemplos recentes da segunda: distinguem entre uma moralidade rotineira, irrefletida (ou pouco refletida) em que as orientações normativas são claras e consistentes e não demandam trabalho de reflexão e uma moralidade em que as pessoas precisam refletir e realizar escolhas entre valores conflitantes. ${ }^{8}$ Neste texto quero me afastar 
de tentativas de recortar com clareza o campo da ética/moralidade do conjunto da vida social, bem como de construir tipologias da ética/moral com base em critérios gerais previamente escolhidos para análise comparativa ${ }^{9}$ - embora, na conclusão, pretenda tecer alguns comentários sobre estas questões. Interessa-me explorar o sentido prático e existencial das obrigações no candomblé. Conforme argumentei acima, obrigação fala de um modo próprio de construir e cuidar de vínculos que define a trajetória dos filhos de santo no terreiro.

Em um texto que trata da inclusão de não humanos na política, a filósofa Isabelle Stengers (2009) recorre ao termo obrigação (obligation, no texto em inglês) para explicar aquilo que entende como prática. O sentido que dá ao termo - embora não coincida com seu emprego no candomblé - oferece uma boa entrada no campo de questões que mobilizam filhos de santo "obrigados". As obrigações que definem uma prática, observa a autora, não operam nem como regras ou injunções arbitrárias a serem obedecidas, nem como normas que fixam ideais de comportamento. Enquanto um comportamento regido por regras ou normas tem seu sentido fixado em termos de critérios gerais de conformidade, obrigações colocam para os praticantes a questão sempre particular e situada de como endereçar e responder àqueles aos quais estão obrigados. Para Stengers, remetem de modo fundamental aos vínculos que em cada prática enredam humanos e não humanos em um devir coletivo: "expressam aquilo que um não humano, seja a Virgem Maria ou neutrinos, demanda [do humano] para que um nó seja criado" (2009:17).

Um dos aspectos salientes dos vínculos que definem o candomblé como prática é que sua construção é objeto de uma série elaborada de rituais que não só tematiza explicitamente o tempo, mas também põe em jogo temporalidades diferentes, articulando durações e qualidades de tempo distintas. Palavras como manutenção, retorno e preparação, usadas por Mãe Beata, além de reiterarem a importância do tempo nas obrigações, apontam para o caráter complexo e multifacetado do tempo na trajetória dos filhos de santo obrigados a seus orixás.

\section{Tempo}

A certa altura da festa em que estive presente no terreiro de Mãe Beata, a roda dos filhos de santo que dançavam para os orixás invocados nos cantos e nos atabaques mais uma vez parou de girar. Permaneceram todos de pé, em círculo - os olhares voltados para a mulher que, cabisbaixa ao lado da mãe de santo, havia saído com ela do roncó (quarto de iniciação), vestida a rigor, 
como compete às adeptas seniores do candomblé (ou ebomis) - calçava sapatos de salto, abertos atrás como tamancos, vestia bata engomada sobre uma saia rodada com anáguas que lhe davam bastante volume, tinha um pano da costa amarrado na cintura e um ojá (torço) amarrado na cabeça com as duas abas laterais erguidas. Entre os seus colares, um, mais grosso, feito com contas grandes de porcelana intercaladas com fios de pequenas miçangas vermelhas, estava amarrado bem rente ao seu pescoço e havia sido usado na sua feitura - o kelê - e outro, feito de contas vermelhas finas com coral, era o colar distintivo de senioridade que ela havia recebido na obrigação de 7 anos - o runjeve. Os demais eram feitos com contas grandes e bastante vistosas e, junto com o runjeve, caíam pesados sobre a bata e, na altura da cintura, eram cobertos pelo pano da costa: o colar de contas de Iansã, a dona de sua cabeça, o de Ogum (seu segundo orixá ou juntó), e o de Logunedé, orixá de sua mãe de santo.

Acompanhavam-na também as duas pessoas que, junto com a mãe de santo, eram responsáveis por ela desde sua iniciação: sua mãe pequena e seu pai pequeno e, quando esse grupo saiu do roncó, foi engrossado por um cortejo de iyas $^{10}$ para dar uma volta no barracão. Então, uma das equedes mais antigas da casa tomou a palavra para explicar aos presentes a razão daquela celebração. A ebomi, filha de Iansã, estava pagando sua obrigação de 14 anos e toda a comunidade estava em festa. Boa filha e boa irmã de santo, a ebomi contava com as bênçãos de sua mãe Iansã e sua presença no terreiro era motivo de muita alegria e orgulho. Uma hora mais tarde, já senhora do corpo da ebomi e paramentada com suas vestes rituais, Iansã dançou soberana: parecia flutuar sobre o chão, com passos rápidos e movimentos ondulados dos braços.

Ao pagar sua obrigação de 14 anos a ebomi, filha de Iansã, galgava mais um degrau na hierarquia do candomblé. É possível dizer que o rito teve como efeito produzir uma mudança no seu status no terreiro. Mas, como bem adverte Bastide (2001), não se deve confundir o sentido de status no candomblé com os significados que o termo usualmente assume na sociologia.

O status social, no interior do candomblé, não traduz apenas ou principalmente uma hierarquia de direitos; não se define tampouco por "papéis", como os sociólogos têm o costume de considerar hoje, ou pela simples posse de encargos, de poderes estabelecidos e admitidos pelos subordinados, nem por normas institucionais. É a imagem do lugar ocupado pelo indivíduo na escala da existência. O status mais ou menos elevado sem dúvida alguma se manifesta exteriormente pelo poder, pelo mando, pela autoridade sobre os indivíduos de status baixo; mas essa autoridade não passa de irradiação do ser, ou, melhor ainda, da quantidade de ser que o orixá possui no indivíduo (Bastide 2001:228). 
Na cosmologia africana, explica Bastide, a existência comporta gradações: somos mais ou menos. A obrigação paga equivale a um incremento de ser: a existência se alarga, se fortalece, o que é expresso em incremento tanto de autoridade e poder de mando quanto de proteção contra os infortúnios.

Embora essa trajetória comporte aparentemente apenas uma única série temporal (em que anos de feitura delimitam os intervalos de tempo entre as obrigações,) trata-se na verdade de duas séries, que na trajetória dos filhos de santo nem sempre coincidem: uma filha de santo que completou sete anos de feitura, por exemplo, está a princípio autorizada a dar sua obrigação de sete anos, mas, conforme explicarei melhor a seguir, isto não significa necessariamente que poderá ou que irá fazê-lo. Assim, há um tempo medido pela contagem dos anos de feitura e um tempo medido pela realização das obrigações. Nenhum dos dois é sem consequência. Mesmo que não esteja acompanhada pela realização das obrigações, a idade de feitura está frequentemente associada à experiência e ao conhecimento acumulados no terreiro. As obrigações dadas, por sua vez, longe de simplesmente imprimirem uma marca pública à passagem dos anos de feitura, transformam a condição existencial da filha de santo. Descuidar delas, como bem observa Bastide, é limitar-se a uma existência diminuída e aos riscos que a acompanham.

Apesar disso, são poucos os filhos de santo que conseguem estar em dia com suas obrigações, pois estas implicam, como a feitura, um investimento considerável de trabalho, tempo e dinheiro. Assim, é comum existirem hiatos por vezes consideráveis entre os anos transcorridos desde a feitura da filha de santo e a realização das suas obrigações. Estes hiatos introduzem um traço temporal próprio na trajetória de muitos adeptos do candomblé: o atraso, o descompasso entre dois tempos (que poderiam coincidir) e, com eles, a dívida. Não pagar a obrigação quando se pode/deve fazê-lo é estar em dívida com o santo. A dívida associa-se também à espera e à negociação. Ao lidar com a exigência da obrigação, filhos de santo estão diante da difícil questão de como honrar o vínculo que os constitui e beneficiar-se dele em condições que raramente são perfeitas (em que lhes faltam recursos e/ou disponibilidade para estar no terreiro, por exemplo). Podem adiar o pagamento de suas obrigações (fazendo oferendas menores para agradar o santo), mas ao fazê-lo enfrentam o risco de trair aqueles a que estão obrigados, os santos (e, é claro, sofrer as consequências da traição).

Para evitar estender por demais o hiato e garantir a realização das suas obrigações, filhos de santo contam com a contribuição da comunidade, em especial daqueles que têm mais recursos, sendo importante sua capacidade de mobilização de redes de auxílio dentro e fora do terreiro. Contam, além disso, com a possibilidade de se juntarem a outros irmãos 
de santo em vias de pagarem suas obrigações, para o período de reclusão e realização dos ritos, o que implica divisão das despesas com a festa e a alimentação. Muitas vezes mães e pais de santo formam esses grupos agregando filhos com menos recursos a aqueles com melhor condição financeira.

Determinar o momento certo para dar uma obrigação não é questão que dependa apenas da vontade da filha de santo e dos recursos que conseguiu assegurar, uma vez transcorrido o lapso de tempo necessário desde sua feitura. Depende da vontade que o orixá expressa e, é claro, do aval da mãe ou pai de santo (que pode considerar que a filha ainda não está pronta para a responsabilidade que acompanha a mudança de status). Há sempre margem de negociação quanto a isso. Mas vale notar que se o atraso prolongado em pagar a obrigação pode ser visto como esquecimento e descuido, o afã de fazê-lo assim que permitido pode ser (mal) visto como pressa em ocupar lugar de mando na hierarquia da casa. E da mesma forma que mães e pais de santo podem dar um empurrão para garantir que uma filha não fique muito tempo em dívida com o santo, também podem frear a pressa de outra, forçando-a a permanecer por mais tempo na condição (inferior) em que se encontra. Como veremos a seguir, permanência e espera, longe de representarem um tempo morto em que que nada acontece, delimitam experiências fundamentais para o sucesso das obrigações. Entender essas experiências requer entender a temporalidade que, seguindo o modelo da feitura, as obrigações instauram.

Talvez a primeira observação a ser feita quanto a isso é que tanto a feitura quanto as obrigações colocam em relevo o tempo progressivo do fazer: desdobram-se através de sequências complexas que envolvem muitos preparativos, participantes e procedimentos e que, uma vez concluídas, produzem e exibem uma obra terminada (embora aberta). As obrigações dão seguimento ao trabalho da feitura. Efetuam, como vimos, um incremento na existência da filha de santo: ela tem mais poder, goza de mais proteção. Também produzem mudança no status do santo, o orixá individual que foi feito com ela, mudanças que se expressam tanto no modo como este se apresenta e é tratado pelos adeptos da casa quanto na sua frequência (diminuem as ocasiões em que irrompe no corpo da filha).

Mas tanto na feitura quanto nas obrigações o tempo progressivo do fazer é tensionado por um movimento de retorno. Como já argumentaram outros estudiosos das religiões de matriz africana (Goldman 2009; Anjos 2009), a relação entre uma iaô (noviça) e o santo que é feito com ela não é criada na feitura: é constitutiva da iaô. Do ponto de vista do candomblé, todo ser humano tem ou é filho de um orixá, embora apenas alguns precisem agir sobre essa condição. Este é o caso daqueles cujo orixá pede a feitura, 
em geral lançando sua filha em um estado de contínua aflição, até que sua vontade seja descoberta e atendida. Não raro, a iaô que é recolhida para a feitura já experimentou sinais da presença do santo em seu passado e, em muitos casos, vínculos com os orixás são parte importante da história de sua família e das gerações que a antecederam.

Isto significa que a feitura realiza um movimento duplo. Por um lado, desdobra-se para frente, passo a passo e através de muito trabalho. Por outro, caminha para trás, conduzindo a iaô ao encontro do passado ou daquilo que ela sempre foi. Para ser bem sucedida, a feitura precisa retornar a iaô ao lugar que é seu (como filha de um orixá ou mesmo como parte de uma família que tem vínculos com os orixás) e conduzi-la para se reapossar do (santo) que já lhe pertence. Assumir uma herança familiar, resgatar um bem esquecido ou até então ignorado e repovoar um território são sentidos desse retorno, que na experiência das iaôs conjugam-se tanto no modo ativo quanto no modo passivo (ser repovoado, ser resgatado pelo orixá). Só através de um retorno pode a feitura colocar a iaô e o santo que é feito com ela numa trajetória de crescimento e maturação que as obrigações fazem avançar.

Na iniciação de equedes e ogãs, conhecida como confirmação, há uma variação interessante desse percurso. Aqui o par iaô-santo, alvo dos procedimentos da feitura, está ausente: equedes e ogãs têm santo, mas não são rodantes, isto é, os santos dos quais são filhos não baixam em seus corpos. Além disso, diz-se que já nascem velhos e por isso não têm que ocupar o lugar de subordinação destinado às iaôs novas, recém-feitas. Adeptos não rodantes, equedes e ogãs servem diretamente ao santo de alguma ebomi rodante (usualmente a mãe ou pai de santo da casa) e são, portanto, equedes ou ogãs daquele santo. ${ }^{11}$. É o santo a quem irão servir que os escolhe (ou "suspende"), em geral, durante alguma função no terreiro, tomando-os pelo braço e exibindo sua escolha aos demais presentes. Embora esta escolha já seja suficiente para mudar a maneira como são tratados (já os torna merecedores da deferência destinada a ogãs e equedes iniciados), ainda precisa ser confirmada para transformar definitivamente seu status no terreiro.

As obrigações também envolvem movimento de retorno. Como já vimos, o vínculo entre a pessoa e o orixá precisa de manutenção. E para manter o que foi produzido na feitura, elas refazem os seus procedimentos. De modo significativo, fazem retornar a filha, cujo ser está em vias de experimentar incremento, ao lugar da feitura: a posição de entrega e subordinação vivida no roncó. Pendendo do pescoço da ebomi na sua obrigação de 14 anos está tanto o runjeve, colar distintivo de senioridade que ela recebeu na obrigação de sete anos e que idealmente carrega sempre consigo, quanto o kelê, colar recebido na feitura como sinal de sua sujeição ao orixá e que, uma vez finda 
a obrigação, retorna para seu lugar de semivisibilidade junto ao assentamento do santo. Camadas de uma sucessão linear são exibidas, justapostas, no corpo da filha em obrigação. Por isso Mãe Beata ressalta a humildade quando fala de práticas que elevam o status da filha de santo.

A humildade é qualidade exigida daqueles que ingressam no candomblé - para muitas iaôs representa um desafio cotidiano. Além disso, é virtude indissociável de sua expressão - precisa ser mostrada através de gestos, posturas e atitudes de submissão. Iaôs lançam-se aos pés dos mais velhos para tomar-lhes a bênção, mantêm a cabeça baixa e seus corpos curvados quando em sua presença e cuidam para obedecer-lhes prontamente. A filha em obrigação necessita retornar ao lugar a iaô nova e abraçar a posição de entrega e sujeição que define esse lugar. De fato, como a iaô recolhida, ela precisa exibir no corpo essa posição para eventualmente vir a ocupar um lugar de mando no terreiro.

A ênfase na exibição chama a atenção para o caráter estético das obrigações (incluindo aqui a feitura): cada etapa é marcada e exibida no corpo, através de vestimentas, pinturas, adereços, gestos e movimentos. Entre uma etapa e outra segue-se um período de repouso que confere um ritmo próprio ao processo como um todo. Esse ritmo e o forte apelo sensível das etapas em curso nos conduzem diretamente para a proximidade entre as transformações operadas na feitura e obrigações e aquelas que se desenrolam na cozinha, proximidade que não passa despercebida do povo de santo e que Mãe Beata evoca no emprego do verbo preparar. A cozinha fala de sequências de atividade e fruição, em que manipular os ingredientes antecipa e prepara o paladar, ou ainda, no caso do terreiro, em que o deleite dos humanos que trabalham e apreciam o que fazem prepara e antecipa o deleite dos orixás que irão comer. Também fala de transformações e seus diferentes ritmos, dos tempos e meios necessários para depurar os materiais e ativar suas propriedades, para produzir certas combinações e deixá-las agir, aguardando seus efeitos. Como já observou Rita Brito (2019), foi a partir do mundo da cozinha que Miguel Deuandá, pai de santo de Mãe Beata, se referiu à sua feitura iminente: "nesse tacho tem dendê, agora é só fritar pra ver no que vai dar".

Preparar é abrir a possibilidade de um acontecimento: tomar as devidas precauções, criar condições favoráveis para um encontro, deixar que as forças aí reunidas possam operar seus efeitos e, como diz Deuandá, aguardar para que estes efeitos se revelem. No seu texto, Mãe Beata enfatiza a necessidade contínua de preparação: antes, durante e depois. Talvez esteja com isso sugerindo que o tempo entre obrigações também seja um tempo de preparação: ao deixar que se assentem os efeitos de processos já concluídos, 
permite que esses processos sejam experimentados como algo consumado. Prepara assim o caminho para novas transformações.

Se a metáfora da oficina funciona como entrada para um mundo que requer manutenção e reparo constante, a cozinha nos joga diretamente em meio a um mundo vivo (de seres que comem e de processos de preparação e distribuição de comida). Nos dois casos, um mundo que não se sustenta sozinho, que sofre desgaste ou se enfraquece e demanda cuidado. Este é certamente um dos sentidos-chave do conceito de obrigação - estar obrigado é encontrar-se diante da necessidade de cuidar, termo bastante usado entre adeptos para falar da relação da filha com o santo que foi feito com ela e cujo sentido relaciona-se tanto à atenção e à destreza do praticante experiente concernido em não deixar sua obra se desgastar quanto à preocupação e ao envolvimento de praticantes com o cultivo de sua prática. Não estamos muito distantes aqui do sentido da palavra "abrigação" criada por Pai Mutá - de fato, da relação estreita entre obrigação e abrigação.

O tempo fornece a chave para entender essa relação, ou melhor, a ética que articula obrigar e abrigar. Como vimos, as obrigações reativam o vínculo entre uma filha humana e o santo que é dono de sua cabeça, vínculo que sofre desgaste ou perde força se não se converter periodicamente em foco de cuidado. Elas recuperam e refazem os procedimentos da feitura, preparando cuidadosamente uma mudança. Voltam à feitura que, longe de ser um ato inaugural, também precisou retornar a uma relação que já estava lá, para instaurar, no terreiro, o par iaô-santo. Diferente da ética cristã que orienta a vida moral das pessoas para uma promessa de redenção futura (a ser conquistada, muitas vezes, através de uma ruptura com o passado), a ética que se desenha no candomblé não põe em relevo o papel redentor do futuro. Mas tampouco trata-se de uma ética assentada na autoridade moral do passado, entendido como começo ou origem: afinal, como vimos, todo começo no candomblé se apresenta, de algum modo, como uma retomada.

Ao refletir, a partir do caso australiano, sobre o potencial de conceitos indígenas para abrir novos campos de prática ético-política e desestabilizar o lugar reservado ao indígena nos colonialismos de povoamento, Elizabeth Povinelli (2011) toca em questões que ressoam diretamente no mundo do candomblé. Que paisagem ética se desenha, pergunta a autora, quando conceitos como reocupação e retorno substituem o de redenção, e o conceito de persistência sobrepõe-se aos de partida e chegada? (2011:28). O ciclo de obrigações no candomblé assenta-se sobre conceitos semelhantes aos evocados por Povinelli. Aqui a ênfase em práticas de manutenção, retorno e preparação afastam o foco da vida moral das pessoas tanto da promessa de salvação do futuro quanto da autoridade moral do passado, ententido 
como origem ou ponto de partida. Nem discurso de origem, nem discurso de redenção, a ética no candomblé emerge como cuidado com um encontro que, antes de se tornar objeto de preocupação explícita, já fez efeito na vida de seus participantes. Quero argumentar agora que esta ética repousa em um pluralismo trabalhoso.

\section{Um pluralismo trabalhoso: ética e política no candomblé}

William James é talvez o grande precursor da reflexão sobre o pluralismo, termo que para ele fala não apenas de um conjunto de valores que deve reger a vida ética e política das pessoas, mas da própria constituição do universo (ou pluriverso). Em Um Universo Pluralista (1920), James delineia sua visão, marcando, passo a passo, a distância que separa o pluralismo de um conjunto de doutrinas rivais. A primeira delas é o materialismo mecânico, doutrina segundo a qual o ser humano é externo à ordem que rege o mundo dos fatos. Para James, o materialismo está ancorado em um hábito geral de receio que exclui a possibilidade de uma relação íntima entre o humano e o mundo. O pluralismo, ao contrário, está associado a um hábito geral de confiança e pertence ao campo das filosofias intimistas ou espiritualistas (termo que ele emprega de forma genérica para cobrir todas as doutrinas antagônicas ao materialismo). ${ }^{12}$. É também sua aposta na intimidade que diferencia o pluralismo de outro representante do campo espiritualista: o dualismo cristão. Ao colocar a criatura humana e a natureza, como ordens distintas sob o comando de um Deus criador onipotente, o dualismo termina por reintroduzir a exterioridade que, no seu combate ao materialismo, se propunha a erradicar.

O pluralismo repousa na ideia de participação íntima entre humano, mundo e divino - base da vertente panteísta do espiritualismo. Mas no esquema de James, pluralismo não é outro termo para panteísmo - neste campo também se encontram as doutrinas absolutistas (que ele chama de monismo racionalista) em oposição às quais a alternativa pluralista ganha contornos mais precisos. Enquanto o absolutismo postula a existência de uma totalidade de nível superior que reúne a diversidade dos conteúdos do mundo, o pluralismo rejeita qualquer ideia de uma realidade inteiramente unificada. ${ }^{13}$. Mas isso não significa que seja equivalente ao atomismo - a uma concepção de mundo como coleção de dados individuais. Ao rejeitar a superioridade do todo sobre as partes, a visão pluralista de James aposta não na ausência de conexão entre as coisas, mas na legitimidade da palavra "alguma": "cada parte do mundo está de algumas formas conectada e de 
algumas outras formas não conectada com suas outras partes, e essas formas podem ser discriminadas, pois muitas delas são óbvias, e suas diferenças são visivelmente óbvias"14 (1920:79).

Ao elaborar a diferença entre pluralismo e absolutismo, James articula esta ideia por meio de um contraste entre dois tipos de ontologias: a forma-cada e a forma-todo. Em uma realidade do tipo forma-todo, a diversidade é subsumida a uma unidade: tudo que existe é conteúdo de um todo, não há resto, nada fica de fora. Já em uma forma-cada, o mundo se faz distributivamente: coisas muito distantes podem estar ou ser conectadas desde que com a ajuda de intermediários, e qualquer conexão, por mais sólida que pareça, corre sempre o risco de ser desfeita. Conexões podem formar teias extensas, mas por maior que seja o alcance dessas teias, nunca arrastam o universo inteiro. Isto significa que há sempre algo de fora que não é nem exterioridade absoluta, nem mera reserva a ser eventualmente absorvida no todo, apenas um resto não integrado, externo àquele modo de conectar, mas não a outros modos possíveis.

As muitas e diferentes obrigações firmadas no candomblé permitem vislumbrar um mundo sustentado por vínculos que precisam ser feitos e requerem manutenção, conexões que podem ser estendidas, mas apenas passo a passo: um universo pluralista no sentido de James, mas um pluralismo com características muito próprias, sobre as quais pretendo falar a seguir. O não entendimento desse pluralismo conduz facilmente à suposição equivocada de que tendo por objeto a relação, sempre única e insubstituível, entre uma pessoa e um santo, a feitura (e as obrigações), justamente por não ultrapassarem esse âmbito pessoal restrito, não podem servir de base para uma ética.

Obrigação no candomblé, entretanto, não é vínculo de dois parceiros apenas. Como já vimos, tem um sentido de retorno que na experiência de muitos filhos de santo implica assumir o peso de uma herança familiar e não raro resulta na reativação de laços na rede de parentesco. No terreiro, a construção e a manutenção de vínculos com os orixás enredam filhos de santo em uma série de obrigações para com aqueles que intervêm nesses processos. A iaô nova é frágil depende diretamente de sua mãe ou pai de santo, da mãe e pai pequeno que estiveram ao seu lado quando foi recolhida, dos mais velhos que atuaram nos procedimentos da sua feitura. Ela está obrigada àqueles que a fizeram. Seu ser é quase uma extensão deles e sua dependência em face deles é uma dimensão importante, embora nem sempre enfatizada, da hierarquia do terreiro. Essa dependência se estende ao santo que é feito com a iaô - nas festas públicas, santo ainda novo (recém-feito) baixa não apenas em resposta aos toques e cantos entoados em sua 
homenagem, mas também quando se canta para o orixá da mãe de santo e da mãe e pai pequenos da iaô. É bem verdade que à medida que a filha de santo paga suas obrigações e sobe na hierarquia da casa, ela ganha autonomia, mas essa autonomia significa que ela se torna cada vez mais foco para novas relações de dependência - cada vez mais existências passam a depender dela.

Longe de se referirem apenas ao par humano-orixá, obrigações formam redes que podem se estender e assumir novos contornos com o processo de maturação e crescimento de seus participantes. Mas se o espaço que desenham é sempre passível de incorporar novas adições, não é por isso menos suscetível de ser, por vezes, encolhido, reduzido à conexão entre a filha humana e as entidades mais-que-humanas que a acompanham. Assim, ebomis podem se valer de sua autonomia para cuidarem por si mesmas de seus orixás; sentindo-se abandonados por seus filhos, mães e pais de santo podem reduzir sua vida no candomblé ao cuidado com os santos que estão assentados na sua casa; às vezes sufocados pelo excesso de conexões que precisam honrar e/ou temerosos de que algumas delas sejam mobilizadas para prejudicá-los, ${ }^{15}$, filhos de santo podem, com maior ou menor sucesso, tentar desvincular o compromisso com o santo da vida no terreiro (reduzindo ao máximo sua frequência ao terreiro, por exemplo). Muitos outros casos deste tipo podem ser identificados, sugerindo que se o espaço moral desenhado pelas obrigações não é simplesmente uma coleção de pequenas ilhas de compromisso e dever, também não é um mundo unificado de antemão. O vínculo entre humano e orixá arrasta consigo outras conexões, mas a força e a extensão dessas conexões varia de acordo com a situação e, é claro, depende dos investimentos práticos de seus participantes.

O terreiro é assim uma rede móvel capaz de conectar, via obrigações, muitas e diferentes entidades. Mas é também um vasto campo de afetos em que nem sempre é possível se distinguir com clareza as fronteiras que separam aqueles que estão conectados. Irmãos de barco (iaôs que são recolhidos juntos para a feitura) sentem seus corpos atravessados pelas mesmas intensidades de afeto: em alguns casos adoecem juntos, sofrem as dores uns dos outros e o castigo que o santo porventura inflige a um deles ecoa também no corpo de seus irmãos. A feitura ajuda a iaô a distinguir a presença do santo no que inicialmente é, para ela, uma experiência confusa de sofrimento. Mas entre a iaô e o santo permanece sempre uma zona de contato e indistinção: não é possível delimitar com clareza onde termina um e começa o outro. Assim também acontece com o assentamento em que o santo reside e que é guardado no terreiro: o assentamento é o santo, 
mas também uma zona de encontro entre o santo, a iaô (que cuida dele) e a mãe ou pai que fez os dois no terreiro (Rabelo 2014).

Além de manterem os vínculos, que a feitura instaurou, entre a filha humana e seu orixá de frente, as obrigações também vinculam a filha aos outros orixás que ela traz consigo. Estendem o trabalho de conexão iniciado pela feitura e, organizadas em uma sequência, regulam as demandas de cuidado que, a cada vez, a filha pode suportar, preparando-a para arcar com as responsabilidades novas e maiores implicadas em cada mudança de status. Assim, enquanto o orixá de frente (o santo de quem a iaô é filha, dono de sua cabeça) come em todas as obrigações, o juntó (seu segundo orixá), em geral, só come a partir da obrigação de três anos, quando começa a baixar no corpo da iaô. A depender do caso e da necessidade, filhos com obrigação de sete anos podem assentar (e, portanto, alimentar) ainda outros dos seus orixás - mães e pais de santo precisam assentar todos.

Mas no candomblé nem todas as obrigações com orixás demandam feitura (e, portanto, o ciclo de obrigações rituais) e orixás não são as únicas entidades mais-que-humanas às quais as pessoas estão obrigadas: há também os erês, entidades infantis ligadas aos orixás; os exus e as padilhas, entidades masculinas e femininas respectivamente que, associadas ao orixá Exu, são ligadas à rua, à sexualidade e à malandragem; e os caboclos, entidades brasileiras, índios, boiadeiros e marujos. Abaixo alguns exemplos, retirados das minhas notas de campo.

Quando cheguei na roça, parte das oferendas de comida seca (que não envolve sacrifício animal) já estava pronta sobre a mesa grande, em um canto do barracão: ao lado do acará para Iansã, havia uma oferenda para Oxossi, feita com milho cozido e enfeitada com fatias de coco sem casca. A iaô que estava recolhida para obrigação de três anos era filha de Iansã, mas não entendi a referência a Oxossi. Depois fiquei sabendo que passara muito mal no dia anterior. Quando Mãe Beata foi ao jogo, Oxossi respondeu. Acompanhava a família da iaô há muito tempo e agora queria também ser cuidado por ela.

Era festa de caboclo e a certa altura Mãe Beata pediu silêncio para o caboclo de uma filha que fazia alguns meses havia completado obrigação de um ano. A presença do caboclo era esperada, porque em outra ocasião ele já havia dado o ar de sua graça, ainda que muito brevemente. Fora logo mandado embora porque a iaô ainda não tinha dado a obrigação de um ano, quando a vinda dos caboclos é finalmente liberada. Desta vez o caboclo foi bem recebido. Ajoelhou-se aos pés da mãe de santo e recebeu dela um cocar de penas coloridas e um arco e flecha. Chegou titubeando, ainda sem conseguir puxar cantiga, as palavras engasgadas, pronunciadas com dificuldade e completadas por quem conhecia o repertório dos caboclos de pena. 
Na comida de exu da casa de Mãe Beata, enquanto padilhas conhecidas sambavam animadamente, paravam para pedir cigarro ou cidra servida na taça, conversar com um e com outro e depois cair de novo no samba, três padilhas novatas chegaram pela primeira vez, anunciando sua presença com uma risada provocadora. Rapidamente se juntaram às companheiras no samba. Mãe Beata se animou e perguntou se por acaso alguma ainda estava sem nome. Queria que se chamasse Erundina. Assim que falou, puxou uma cantiga: Erundina, Erundina....

A sequência das obrigações rituais que seguem à feitura procura impor alguma ordem sobre como e quando os vínculos com os orixás são construídos. Até mesmo os caboclos, externos ao panteão das divindades africanas, são instados a se ajustar a ela: se chegam antes da iaô dar sua obrigação ritual de um ano, são mandados embora, convidados a esperar. Apesar disso, o movimento de criação de vínculos no candomblé nunca se adéqua inteiramente ao modelo geral, não apenas porque cada caso é único, mas porque novas solicitações estão sempre a bater na porta dos terreiros e na vida das pessoas. E, como ilustram os exemplos acima, algumas delas exigem de pais e filhos de santo que participem de modos diferentes de construir e cultivar vínculos. Orixás herdados podem intervir na relação entre a pessoa e o orixá que é dono de sua cabeça, demandar cuidado na forma de oferendas periódicas ou mesmo requerer assentamento (sem que a relação com eles exija feitura). Entidades como caboclos, exus e padilhas podem chegar quando não são esperadas e sem serem chamadas. Podem mesmo resistir a tentativas de conter ou regular sua presença. E, como bem sabem mães e pais de santo, responder a elas - ofertando-lhes nome, comida ou adereços - já é se "obrigar". ${ }^{16}$

James ressalta que, nas ontologias pluralistas (forma-cada), o mundo é feito distributivamente e, por mais extensas que sejam as redes conectando as entidades do mundo, sempre sobra um resíduo. O conceito de linha mobilizado por praticantes das religiões de matriz africana aponta para um modo interessante de fazer conviveram as diferenças e permitir uma experiência de resto. As linhas acentuam diferenças no modo como humanos respondem às solicitações das entidades, procurando atuar de acordo com o tipo de energia, inclinação ou disposição destas últimas: pode-se dizer que cada linha define um modo diferente de se estar obrigado. Não há uma classificação única das linhas. Talvez a mais conhecida seja aquela que separa linha de azeite de linha branca, definidas pela exigência ou não do sacrifício animal (presente na linha do azeite, ausente na linha branca). Há terreiros que trabalham apenas com uma linha; outros trabalham com mais de uma.

Em sua dissertação de mestrado, Luisa Damasceno (2017) foi surpreendida com uma forma pouco usual de emprego do termo: os integrantes 
do terreiro Oiá Mucumbi, no Recôncavo Baiano, referiam-se não apenas às já conhecidas linha de azeite e linha branca, mas falavam dos católicos e dos evangélicos como também pertencendo a linhas - a linha católica e a linha de crente. A primeira era representada, no terreiro, por uma pequena capela dedicada à Santa Bárbara: todo ano, no dia da santa, um padre costumava vir rezar missa na capela. A segunda, linha de crente, era externa ao terreiro e permanecia para seus habitantes um resto não integrado - nem o inimigo a ser eliminado, nem uma reserva de gente a ser conquistada para o candomblé. Se as linhas branca e do azeite efetivamente se articulam no Oiá Mucumbi, e a linha católica mantém com elas alguma conexão, o mesmo não se pode dizer da linha de crente. Para os filhos do Oiá Mocumbi, entretanto, isto não impede que eles se conectem por algum outro tipo de vínculo a pessoas da linha de crente ou mesmo que alguma conexão futura venha a ligar essas quatro linhas.

Até agora abordei o sentido de obrigação no candomblé, investigando o modo com que os vínculos são construídos e mantidos nos terreiros. Gostaria de concluir esta seção em outra chave: voltando a uma discussão sobre obrigações a partir de uma situação de quebra - um conflito que se desenrolou nas redes sociais e ao qual tive acesso por indicação de um colega.

Há aproximadamente três anos um filho de santo de um antigo e tradicional terreiro de candomblé foi oficialmente desligado do terreiro e seu desligamento informado em uma nota oficial divulgada no Facebook. O filho punido era ele mesmo pai de santo com casa aberta em outra cidade (e será aqui referido como filho/sacerdote). Seu vínculo com o terreiro do qual estava sendo afastado (que chamarei de casa matriz) datava de quase 30 anos. As razões que justificavam medida tão drástica estavam elencadas na nota e giravam em torno de um acontecimento que teve o filho/sacerdote como protagonista. Ele confirmara em seu terreiro - isto é, iniciara como seu filho de santo e como ogã de seu orixá - um jovem que já havia sido suspenso na casa matriz pelo santo de uma adepta desta casa. Conforme salientava a nota, desrespeitara com isso o próprio orixá da adepta que, em ritual público na casa matriz, apontara o jovem para atuar a seu serviço como ogã Embora o rapaz ainda não tivesse sido iniciado na casa matriz, a escolha do orixá já constituía um vínculo espiritual e, portanto, deveria ter sido mantida. Além disso, dizia a nota, o filho/sacerdote desrespeitara a hierarquia, princípio basilar do candomblé, pois tendo sido advertido pelo ocupante de um dos cargos mais elevados da casa matriz contra a confirmação do ogã em seu terreiro, havia seguido adiante com sua decisão de fazê-lo. 
A resposta do sacerdote afastado não demorou e também saiu nas redes sociais. ${ }^{17}$ Ao manifestar seu profundo descontentamento com a punição, ele relembrou sua longa trajetória no candomblé - em especial, seus vínculos com o terreiro chefiado por sua mãe biológica (cujo legado ele havia assumido) e com o terreiro no qual havia sido iniciado. Ressaltou seus muitos anos de dedicação à casa matriz, à qual chegou depois do falecimento de seu pai de santo, para dar a obrigação de sete anos. E uma vez concluída a apresentação de seu passado no candomblé, discorreu sobre o terreiro que ora chefiava, terreiro onde agora estavam filhos e netos que haviam sido banidos, junto com ele, da casa matriz. Depois de enumerar os vínculos que o fizeram, tratou dos vínculos que no presente era responsável por sustentar.

O filho/sacerdote criticou não só seu desligamento da casa matriz, mas também a divulgação do fato nas redes sociais - servia para abalar sua reputação pessoal, mas, com ela, tingia a própria reputação do candomblé. A seu favor argumentou que o ogã que ele havia confirmado não era ainda filho da casa matriz, mas apenas um aspirante a essa condição, afinal como ogã suspenso permanecia abiã (adepto não iniciado). Também chamou a atenção para o fato de que não havia afinidade entre o rapaz e a adepta cujo santo o suspendera na casa matriz. "Pertencemos a um culto que, se não existir afinidade, amor e respeito, nada dará certo energeticamente" escreveu. E observou que a adepta em questão não só se encontrava afastada da casa matriz, como ainda não havia dado obrigação de sete anos (o que impedia o santo que foi feito com ela de ter um ogã a seu serviço).

Além disso, considerando que o ogã residia próximo à casa matriz e muito distante de seu terreiro (localizado em outro estado), o filho/sacerdote explicou que o rapaz, mesmo confirmado na sua casa, poderia bem continuar servindo à casa matriz, ajudando nas tarefas que, como abiã, já se encarregava de desempenhar. Afinal, ele, sacerdote, não pertencia também à casa matriz?

Em todas as suas postagens, o filho/sacerdote ressaltou a questão da liberdade. Primeiro, criticou a casa matriz por sufocar a liberdade de escolha dos seus filhos e observou que o tempo da escravidão já findara. Também destacou sua liberdade de fala, insistindo que tendo sido feito, há muitos anos, pelas mãos do seu já falecido pai de santo, já não era mais criança e tinha direito de expressar seu descontentamento em face das acusações de que era alvo. E invocou o direito de escolha do ogã, acrescentando que fazia muito tempo que o rapaz aguardava pela oportunidade de ser confirmado.

Por fim, disse estar convencido de que a decisão de bani-lo da casa matriz não partira do orixá da casa, "das pedras e dos ferros daquela casa que bem sabem quem lhes serve com honra e dedicação". ${ }^{18}$ 
O conflito se desdobrou nas redes sociais com mensagens de integrantes e simpatizantes das duas partes. Envolveu muitas outras questões, além das citadas acima, cuja discussão exaustiva está fora do escopo deste trabalho. Aqui me interessa tão somente tirar algumas conclusões a partir dos dilemas e dos argumentos relativos às obrigações que cada uma das partes afirmava terem sido traídas pela outra, obviamente sem qualquer pretensão de determinar ou mesmo avaliar quem estava certo.

Talvez a primeira coisa a notar é que permanecia matéria de disputa não só o número e a identidade dos envolvidos, mas o papel de cada um pelo desdobramento dos eventos. Qualquer que fosse a versão do ocorrido, entretanto, a vontade dos orixás figurava sempre como elemento fundamental do caso: saber discernir e respeitar essa vontade aparecia nos textos postados como questão crucial para as duas partes. ${ }^{19} \mathrm{O}$ drama colocou em evidência os vínculos que definem as pessoas no candomblé e sua relação estreita com a questão da responsabilidade. Basta notar como nos relatos os participantes eram definidos e se apresentavam. O ogã era tratado como uma existência ainda fraca - passara muito tempo na condição de abiã e, recém-confirmado, dependia da força dos seus mais velhos: por isso a punição dirigia-se diretamente ao sacerdote que o iniciara e o atingia através deste. O filho/sacerdote punido estava na posição oposta e podia falar pelo ogã. Não apenas contava com os vínculos que, no passado, o constituíram, como também com aqueles que no presente o tornavam responsável pela constituição de seus próprios filhos de santos. No seu relato, a enumeração desses vínculos é uma declaração de sua força, mas também funciona para relativizar sua dependência e seu compromisso com respeito à casa matriz. Afinal, quando chegou lá para dar a obrigação de sete anos, "já tinha feito todos os ebós de encantamento"20 - isto é, comungava só parcialmente do axé da casa matriz.

As muitas questões levantadas pelas partes em disputa não apenas evidenciam a importância das obrigações no cotidiano dos terreiros, como também expõem um dos problemas-chave que confrontam as pessoas no candomblé: como discernir quem conta e em que medida cada um conta no desdobrar dos eventos, quando se tem um mundo composto por muitas e diferentes relações de dependência, afinidade, atração? Vejamos algumas dessas questões: O que é mais importante nesse caso, o vínculo espiritual criado pela escolha do orixá que suspendeu o ogã na casa matriz ou o tipo de vínculo que, como adepto ainda não iniciado, o ogã suspenso mantinha com essa casa e que ainda não o tornava integrante pleno dela? A idade do santo que suspendeu o ogã na casa matriz enfraquece de algum modo a exigência de que o ogã se submeta à sua escolha? A escolha do santo obriga o ogã 
suspenso a permanecer na casa matriz ou sem a confirmação essa escolha é apenas um convite que ele pode ou não aceitar? A afinidade (simpatia, proximidade) entre o ogã e a filha humana do santo que o suspendeu conta na definição da situação?

Esta última questão é particularmente interessante. Ao sugerir que o sucesso do vínculo entre um santo e a pessoa que ele escolheu como ogã depende também de uma afinidade entre este último (o ogã suspenso) e a filha humana que roda com aquele santo, o sacerdote punido ilumina uma variante interessante do problema a que me referi acima. Penso que pode ser enunciada nestes termos: como discernir quem conta quando as fronteiras separando os seres obrigados (neste caso, o santo e sua filha humana) estão frequentemente borradas, e o entre-eles é preenchido por zonas de indiferenciação?

A esta altura cabe tratarmos do lugar reservado à vontade e à liberdade em um mundo feito de obrigações. O sacerdote punido colocou bastante ênfase no valor da liberdade de escolha, criticando os terreiros que querem subjugar seus filhos com prescrições e punições rígidas demais. Estaria ele relativizando o peso das obrigações no candomblé ou mesmo abraçando uma moralidade de tipo diferente, pautada no valor atribuído ao indivíduo autônomo? Se considerarmos a importância que confere à enumeração dos seus vínculos (tanto com os diferentes seres que contribuíram para sua feitura quanto com os outros que, como pai de santo, ele ajudou a fazer), sugiro que ao invés de se afastar da moralidade das obrigações, o sacerdote estava a reivindicar atenção à vontade do ogã como mais um elemento na cadeia através da qual a relevância do evento se estabelece: por mais fraco que seja o filho de santo numa escala de existência, sua vontade ainda conta. Assim, a questão não é escolher entre liberdade ou obrigação, senão saber em que momento o exercício da vontade se converte em traição dos vínculos.

\section{Algumas outras questões, para concluir}

Em um encontro que reunia dois grupos de pesquisa sobre religiões afro-brasileiras da UFBA foi discutido um pequeno texto, de autoria de um dos participantes, que tinha como pivô o julgamento sobre o sacrifício de animais em rituais religiosos em andamento no STF. Um dos temas brevemente abordados no texto gerou um debate acalorado: a questão da palavra matança, ou mais especificamente dos seus efeitos sobre o modo como o candomblé se apresentava e era visto por amplos setores da sociedade. Também foram elencadas e discutidas algumas das alternativas defendidas 
para sua substituição: sacrifício, oferenda, sacralização. O debate nos mobilizou não apenas como pesquisadores, mas também como simpatizantes e adeptos do candomblé (dos aproximadamente dez participantes, sete eram iniciados, inclusive eu). Duas posições logo se delinearam, sem que sua formulação tivesse conduzido a qualquer polarização rígida. A primeira ponderava que a troca de nome e, em particular, de um nome tão enraizado no cotidiano dos terreiros, como matança, não deixava de ser uma atitude de subserviência, em que a apresentação pública assumia prioridade sobre o modo como o povo de santo definia e falava do candomblé. A segunda posição centrava-se no argumento de que, em um contexto de intolerância e agressão crescente às religiões afro-brasileiras, era preciso construir pontes, forjar alianças: se a palavra matança era um empecilho a isso, então poderia bem ser substituída por outra mais palatável aos ouvidos da gente de fora e ainda assim capaz de traduzir o sentido da utilização de animais nos rituais de candomblé. O problema é que para aqueles que se alinhavam à primeira posição, os termos substitutos pareciam versões incompletas ou domesticadas demais.

Foi durante essa reunião de pesquisa que o autor do texto se referiu à entrevista de Tata Mutá a Jô Soares. Dias depois, quando assisti à entrevista no YouTube, percebi que a questão da matança, colocada por Jô, remetia justamente ao sentido fortemente negativo que a palavra assume para ouvidos não treinados no mundo do candomblé. Após perguntar sobre as obrigações, o entrevistador disparou: tem matança?

Dei-me conta, então, de que a fraqueza da primeira posição estava na maneira como articulava o problema, tratando-o em termos de uma alternativa entre preservar uma essência do candomblé ou apresentar uma boa imagem aos de fora. A segunda posição, nesse sentido, era mais interessante. No lugar da alternativa, propunha uma conjunção - preservar aquilo que define o candomblé e se conectar, ou mesmo, se conectar com outras práticas (acadêmicas, artísticas ou políticas, por exemplo) para preservar/proteger o candomblé. Essas conexões não precisavam conduzir a uma perfeita identidade entre as partes ou a uma absorção de umas pelas outras. Por isso, argumentava-se a favor de usar o termo "sacrifício" nas relações com não praticantes e reservar "matança" para as interações no terreiro e entre os praticantes das religiões de matriz africana. Apostava-se na possibilidade de "alguma" conexão e abria-se caminho para uma experiência de resto (de elementos de ambos os lados que estariam fora da aliança a ser construída) - uma sabedoria do pluralismo. Isto não tornava o problema menos complicado ou seu enfrentamento menos arriscado. Afinal, colocava-se agora o desafio de falar de outro modo e para outros praticantes de coisas que são caras 
ao candomblé. Tata Mutá encarou esse desafio ao propor o termo abrigação como substituto para obrigação.

Vale notar que, ao tratar desse evento, desloquei ligeiramente o tema que constituiu o foco deste texto: comecei com uma discussão sobre o modo como vínculos são construídos no terreiro e concluí descrevendo um breve debate sobre as possibilidades, os limites e os perigos envolvidos na construção de alianças entre terreiros e outros universos de prática. À primeira vista estas duas situações - construção de vínculos no interior dos terreiros e a criação de alianças fora do terreiro - parecem oferecer exemplos perfeitos do contraste entre ação moral irrefletida e ação moral reflexiva a que me referi no início do texto. Com base na tipologia de Robbins (2007), seria possível dizer que, seguindo regras bem delimitadas e relacionadas a um sistema de valores único, a construção de vínculos no interior dos terreiros seria um exemplo de prática moral que requer pouca ou nenhuma reflexão; já os esforços para tecer alianças com outras práticas, falar do candomblé para acadêmicos, estudantes, artistas e/ou políticos e mobilizá-los em defesa dos terreiros enfrentariam o desafio de lidar com sistemas de valores possivelmente conflitantes, exigindo reflexividade aguçada dos atores envolvidos. O contraste, entretanto, está longe de descrever bem como obrigações são firmadas, seja no interior do candomblé, seja entre o candomblé e outros universos de prática: como já vimos, problemas que demandam reflexão surgem a todo tempo nos terreiros, modulando o modo como vínculos são aí construídos, e qualquer que seja a dimensão ou a novidade de um problema como aquele retratado na reunião de pesquisa, a reflexão que suscita não deixa de se alimentar de soluções preferenciais, hábitos e inclinações operando em um nível irrefletido ou pré-reflexivo.

Apesar de diferentes, as questões levantadas nas redes sociais por ocasião do banimento do pai de santo e aquelas colocadas pelos estudiosos-praticantes do candomblé no encontro da UFBA não pertencem a universos fechados, com pouca relação entre si. É preciso considerar seriamente que os caminhos e os procedimentos adotados nos terreiros para manter as pessoas conectadas podem bem acenar com pistas para outras conexões envolvendo o candomblé.

Tomados em conjunto, esses dois eventos revelam tanto a delicadeza de um mundo composto por vínculos que requerem cuidado constante quanto a sua resiliência. Também oferecem lições para uma antropologia da moral. O primeiro caso sugere que estudar a construção de vínculos através de situações de quebra ajuda a pesquisadora a encontrar a moral lá onde ela ganha sua significação mais plena: não onde pode ser separada com clareza de outros campos de prática, mas em meio aos problemas concretos que 
mobilizam as pessoas. O segundo, por sua vez, lembra que se a vida moral não pode ser separada dos problemas que confrontam uma prática, estes não vêm prontos, precisam ser articulados. Reduzir a moralidade à aplicação de regras a problemas conhecidos é subtrair a experimentação da prática moral, como também o risco e a hesitação que a acompanham. ${ }^{21}$

Recebido em: 04 de setembro de 2019

Aprovado em: 04 de março de 2020

Miriam C. M. Rabelo

Professora do Departamento de Sociologia e Programa de Pós-Graduação em Ciências Sociais da Universidade Federal da Bahia. Desenvolve pesquisa sobre religiões de matriz africana no Brasil, com foco especial em questões relativas às práticas ético-políticas e estéticas dessas religiões.

https://orcid.org/0000-0002-5212-6129

E-mail: mcmrabelo@uol.com.br 


\section{Notas}

1 Este texto é fruto de pesquisa desenvolvida com apoio do CNPq. Durante a preparação da versão final contei com apoio da Capes (através de bolsa do programa Capes-Print).

2 Os terreiros de candomblé se diferenciam segundo nações, termo que se refere a tradições rituais originárias dos diferentes grupos étnicos associados à formação do candomblé. São três as principais nações de candomblé: a keto, que recebe sua marca dos iorubá; a jeje, dos fon, e a angola, dos banto. Cada nação cultua um tipo diferente de divindade: orixás no keto; voduns no jeje e inquices no angola. Embora essas divindades apresentem várias correspondências (evocadas pelos próprios praticantes), as línguas rituais, os ritmos musicais, as danças e muitos procedimentos envolvidos no seu culto são diferentes.

3 O termo rodante, que designa a condição existencial de estar aberto à possessão pelo orixá, está ligado à expressão "rodar com santo", usada quando alguém está possuído ou foi pego pelo orixá. Nem todos os adeptos do candomblé são rodantes. Homens não rodantes são iniciados como ogãs e no terreiro desempenham funções especializadas como tocar os atabaques (alabês), presidir os sacrifícios animais (axoguns) e receber visitantes (ogãs de sala). Mulheres não rodantes são iniciadas equedes e são responsáveis pelo cuidado com santos que baixam no terreiro, o que inclui também cuidado com suas vestimentas e objetos rituais. Só adeptos rodantes podem aspirar à condição de mãe ou pai de santo.

4 É importante notar que, embora existam algumas interdições à mistura de laços de parentesco consanguíneo e de santo, familia de sangue e família de santo estão entrelaçadas de diversas formas nos terreiros de candomblé (ver a este respeito Flaksman [2018]). É muito comum encontrar verdadeiras redes familiares no interior de um terreiro, inclusive parentes da mãe ou pai de santo (filhos, netos, sobrinhos, irmãos etc.) que são feitos no santo; não raro, a sucessão da casa se dá no interior deste último grupo. Conforme mostra Flaksman (2018), o vínculo com os orixás, e mesmo com certos orixás específicos, perpassa a história de linhagens familiares do candomblé; em alguns casos, pessoas herdam o santo de parentes falecidos.

5 Os orixás gerais diferenciam-se em termos de qualidades que ressaltam alguns traços de temperamento, idade, eventos que protagonizaram ou algumas de suas relações com outros orixás. Assim, entre as qualidades do orixá Ogum, tem-se Ogum Xoroquê, que é um Ogum bastante próximo do orixá Exu, Ogum Meje, o Ogum mais velho, e Ogum-Já, ligado a Oxaguiã e Iemanjá.

6 Há certa variação quanto a isso. Em algumas casas, por exemplo, dá-se também obrigação de 5 anos.

7 Vale notar que estou usando os termos ética e moralidade aqui de forma intercambiável. Embora atenta ao fato de que várias distinções entre os dois tenham sido propostas tanto na filosofia quanto na antropologia (ver a este respeito as 
discussões de Lambek [2010] e Faubion [2011]), não me parece que recortar com precisão esses campos ofereça contribuição importante para o entendimento do sentido prático e existencial de obrigação no candomblé, que constitui o objetivo desses textos.

8 Enquanto Robbins toma essas duas moralidades como relativas a contextos culturais e históricos distintos - culturas em que um sistema de valores dominante fornece às pessoas orientações normativas claras para agir e culturas em que coexistem e competem configurações valorativas conflitantes - Zigon toma a alternância entre elas como parte de vida das pessoas em qualquer contexto social.

9 Disso decorre que não busco provar que no candomblé haja uma ética (o que não me parece requerer prova alguma, exceto se optarmos por definir ética como reunião de conteúdos gerais previamente definidos).

10 Literalmente, mães. Engloba todas as filhas de santo rodantes que já detêm senioridade no terreiro (i.e., já deram obrigação de sete anos e são, portanto, ebomis).

11 Assim, uma equede (ou um ogã), como qualquer outra filha de santo, tem um orixá de frente (que é o dono de sua cabeça), mas é equede do santo que a suspendeu no terreiro, do orixá individual de uma ebomi rodante.

12 Em um universo pluralista, a externalidade entre experiência e mundo, postulada de modo radical no materialismo, é substituída pela intimidade: o mundo não é um território estrangeiro para a experiência. Ou, como observa Connolly, "a natureza já não é mais tratada como se fosse radicalmente diferente da experiência humana da liberdade e do tempo" (2005:69).

13 Para James, ao pressupor uma distância incontornável entre o ponto de vista absoluto (eterno) do todo e o ponto de vista relativo (temporal) da experiência, o absolutismo traz para dentro do panteísmo "barreira quase tão grande à intimidade entre o divino e o humano, como a que encontramos no teísmo monárquico" (1920:40).

14 No original "each part of the world is in some ways connected, in some other ways not connected with its other parts, and the ways can be discriminated, for many of them are obvious, and their differences obvious to view".

15 As conexões de que participa no terreiro implicam para uma filha de santo que muita gente tem acesso direto a ela e, em especial, ao seu santo que está aí assentado, podendo se valer desse acesso para fazer algum feitiço contra ela.

16 Há bastante variação na abertura dos terreiros para acolher as diferentes demandas que chegam e enredam seus filhos humanos em novas obrigações.

17 É importante notar que se a publicização via redes sociais de tensões e punições envolvendo filhos de um terreiro ou mesmo de terreiros diferentes é algo relativamente recente, o tipo de conflito aqui abordado está longe de ser novo no candomblé.

18 Ao falar das pedras e dos ferros, o filho/sacerdote se refere aos assentamentos dos orixás. 
19 Reduzir o drama a uma queda de braço entre atores humanos interessados em acumular prestígio conduz a um apagamento daquilo que para o povo de santo define sua prática e os obriga. Reconhecer isto não torna o evento menos conflituoso: apenas revela nele a atuação de outras entidades que não as humanas - muitas das quais precisam de porta-vozes sensíveis a seus apelos - o que torna o problema mais complicado e o conflito mais apaixonado.

20 O sacerdote refere-se aqui a ebós (oferendas) que fazem parte do processo de feitura.

21 Pode-se dizer que a primeira observação tem um caráter mais metodológico e serve de alerta contra o intelectualismo e suas tentativas de "limpar" o terreno da moral da interferência de elementos contextuais que, por definição, lhe seriam alheios. A segunda protege contra definições muito estreitas de prática moral, que excluem dela a imaginação e a criatividade. 


\section{Referências bibliográficas}

ANJOS, José Carlos dos. 2009. "A iconoclastia afro-brasileira na Festa de Nossa Senhora dos Navegantes em Porto Alegre". In: $33^{\circ}$ Encontro Anual da Anpocs, Caxambu.

BASTIDE, Roger. 2001. O Candomblé da Bahia. São Paulo: Companhia da Letras.

BRITO, Rita. 2019. "É comadre: aí tem dendê, quando fritar vamos ver no que vai dar". In: VII Congresso da Associação Portuguesa de Antropologia - APA, Lisboa.

CONNOLLY, William E. 2005. Pluralism. Durham: Duke University Press.

DAMASCENO, Luisa. 2017. Linhas, Tramas e Caminhos: seguindo os movimentos de um candomblé do Recôncavo da Bahia. Dissertação de Mestrado, Universidade Federal do Recôncavo da Bahia.

DURKHEIM, Emile. 2003 [1912]. As Formas Elementares da Vida Religiosa. São Paulo: Martins Fontes. FAUBION, James. 2011. An Anthropology of Ethics. Cambridge: Cambridge University Press.

FLAKSMAN, Clara. 2018. "'De sangue' e 'de santo': o parentesco no candomblé". Mana, 24 (3):124150. http://dx.doi.org/10.1590/167849442018v24n3p124

GOLDMAN, Márcio. 2009. "Histórias, devires e fetiches das religiões afrobrasileiras: ensaio de simetrização". Análise Social, XLIV (190):105-137. http://analisesocial.ics.ul.pt/documento s/1236787453Q7qNY4ou6Fl23NG6.pdf
JAMES, William. 1920. A Pluralistic Universe. New York: Longman, Green \& Co.

LAMBEK, Michael. 2010. "Introduction". In: M. Lamkek (org.), Ordinary Ethics: Anthropology, Language and Action. Nova York: Fordham University Press. pp. 1-36.

PARSONS, Talcott. 2010 [1937]. A Estrutura da Ação Social. Petrópolis: Vozes.

POVINELLI, Elizabeth. 2011. "The Governance of the Prior". Interventions: International Journal of Postcolonial Studies, 13 (1):13-30. http://dx.doi.org/10.1080/136980 1X.2011.545575

RABELO, Miriam C.M. 2014. Enredos, Feituras e Modos de Cuidado: dimensões da vida e convivência no candomblé. Salvador: Edufba.

ROBBINS, Joel. 2007. "Between Reproduction and Freedom: Morality, Value, and Radical Cultural Change". Ethnos, 72 (3):293-314. http://dx.doi. org/10.1080/00141840701576919

STENGERS, Isabelle. 2009. "Including Nonhumans in Political Theory: Opening Pandora's Box?". In: Bruce Braun \& Sarah J. Whatmore (orgs.), Political Matter: Technoscience, Democracy, and Public Life. Minneapolis: University of Minnesota Press. pp. 3-34.

ZIGON, Jarret. 2007. "Moral breakdown and the ethical demand. A theoretical framework for an anthropology of moralities". Anthropological Theory, 7:131-150. https://doi.org/10.1177/1463499607077295 


\section{OBRIGAÇÕES E A CONSTRUÇÃO DE VÍNCULOS NO CANDOMBLÉ}

\section{OBLIGACIONES Y LA CONSTRUCCIÓN VÍNCULOS EN EL CANDOMBLÉ}

\section{Resumo}

Obrigações no candomblé são ritos realizados após a feitura (iniciação) para fortalecer os laços entre a filha de santo e seu orixá; a sequência desses ritos descreve uma trajetória de crescimento e maturação no terreiro. Em um sentido mais amplo, o conceito de obrigação fala de um modo próprio de criar e manter vínculos cujas dimensões temporais, éticas e políticas exploro ao longo deste texto. As muitas e diferentes obrigações construídas e por vezes rompidas no candomblé revelam um universo pluralista, próximo do sentido que William James atribui ao termo, embora um tipo muito particular de pluralismo, cujas características procuro descrever. Palavras-chave: Obrigação, Ética, Pluralismo, Candomblé.

\section{Resumen}

Las obligaciones en el candomblé son ritos realizados después de la iniciación para fortalecer los lazos entre la hija de santo y su orisha; la secuencia de estos ritos describe un camino de crecimiento y maduración en el terreiro. En un sentido más amplio, el concepto de obligación habla de una forma propia de crear y mantener vínculos cuyas dimensiones temporales, éticas y políticas exploro a lo largo de este texto. Las muchas y diferentes obligaciones construidas y algunas veces rotas en el candomblé revelan un universo pluralista próximo al sentido que William James atribuye a este término, aunque un tipo muy particular de pluralismo, cuyas características trato de describir.

Palabras clave: Obligación, Ética, Pluralismo, Candomblé. 


\title{
OBLIGATIONS AND THE \\ CONSTRUCTION OF TIES IN \\ CANDOMBLÉ
}

\begin{abstract}
Obligations in the Candomblé refer to rites that are performed after initiation to strengthen ties between an adept and her orixá; these rites form a sequence that describes a trajectory of growth and maturation. In a broader sense, the concept of obligation points to a mode of building and maintaining ties that has important temporal, ethical and political dimensions which I explore throughout the paper. The many different obligations that are made and sometimes broken in the candomblé reveal a pluralistic universe, close to William James' definition of the term, albeit a very particular kind of pluralism whose features I seek to describe

Keywords: Obligations, Ethics, Pluralism, Candomblé.
\end{abstract}

